\title{
Strategi Pemasaran Karya Seni Lukis Di Kampung Seni Budaya Jelekong
}

\author{
Marina Yuliani ${ }^{1}$, Kiki Zakiah ${ }^{2}$ \\ ${ }_{1,2}^{1}$ Universitas Islam Bandung \\ E-mail: ${ }^{1}$ marinayuliani98@gmail.com, ${ }^{2}$ kikizakiahdarmawan@gmail.com
}

\begin{abstract}
The art of painting from 'Kampung Seni Budaya Jelekong' has spread to foreign countries. The aims and objectives of this research are to comply with the marketing strategies of painting works in Jelekong Art and Culture Village which are marketed by the artist community to advance Kampung Seni Budaya Jelekong' so that it is known by the wider community. This research was conducted using qualitative research through the case study method. Data obtained through in-depth interviews, observation, and documentation. The subject of this research is someone who is one of the managers of Gurat and a painter who manages the 'Kampung Seni Budaya Jelekong'. While the theory used is the 7P Marketing mix carried out by the artist community in Jelekong. Based on the research results obtained, the marketing of paintings in 'Kampung Seni Budaya Jelekong' carries out its promotions which include personal selling, public relations, direct marketing, events, sales promotion. From the overall form of promotion mix, which is the main priority of promotion is carried out by public relations, direct marketing, and events. The results of this study can be concluded that the marketing strategy of painting in Jelekong has used the 7P marketing mix.
\end{abstract}

Keywords: marketing strategy, 7P Marketing Mix, Kampung Seni Budaya Jelekong, Painting art

\begin{abstract}
ABSTRAK
Seni lukis asal Kampung Seni Budaya Jelekong sudah tersebar ke manca negeara. Daerah yang sebagian besar masyarakatnya berlatar belakang seniman itu tentunya dalam melukis mempunyai potensi besar untuk mengenalkan kampung tersebut kepada khalayak luas. Maksud dan tujuan dalam penelitian ini adalah untuk mengetatuhi bagaimana strategi pemasaran karya seni lukis di Kampung Seni Budaya Jelekong yang dipasarkan oleh komunitas seniman untuk memajukan Kampung Seni Budaya Jelekong agar diketahui oleh masyarakat luas. Penelitian ini dilakukan dengan menggunakan penelitian kualitatif melalui metode studi kasus. Data yang diperoleh melalui wawancara mendalam, observasi, dan dokumentasi. Subjek penelitian ini adalah seseorang yang merupakan salah satu pengelola Gurat dan pelukis yang mengelola Kampung Seni Budaya Jelekong. Sedangkan teori yang digunakan adalah bauran pemasran 7P yang meliputi (Product, Place, Price, Promotion, People, Physical Evidence, dan Process) yang dilakukan oleh komunitas seniman di Jelekong. Berdasarkan hasil penelitian yang diperoleh pemasaran lukisan di Kampung Seni Budaya Jelekong menjalankan promosinya yang meliputi personal selling, public relations, direct marketing, event, sales promotion. Dari keseluruhan bentuk promotion mix, yang menjadi prioritas utama promosi dilakukan public relations, direct marketing, serta event. Hasil penelitian ini dapat disimpulkan bahwa strategi pemasaran seni lukis di Jelekong sudah menggunakan bauran pemasaran 7P.
\end{abstract}

Kata Kunci: Strategi pemasaran, Bauran Pemasaran 7P, Kampung Seni Budaya Jelekong, Seni lukis 
Jurnal Manajemen dan Bisnis: Performa Vol. 18, No. 2 September 2021

\section{PENDAHULUAN}

\section{Latar Belakang}

Beragam karya seni lukis di setiap daerah membuat tingginya persaingan antara pelukis satu dan lainnya dalam memasarkan produknya. Mengingat masuk tahun 2000-an perkembangan 'pasar seni rupa' di Indonesia mengalami pertumbuhan yang sangat pesat terutama dalam pencapaian karya maupun produk. Menurut (Suwitya, 2020) yang meneliti strategi pemasaran seni lukis di daerah Jogja, Yogyakarta lah yang dicatat sebagai 'kota seni rupa' yang diperhitungkan di Indonesia diatas kota seni kreatif seperti: Bandung, Jakarta dan Denpasar diperhitungkannya sejak ada istilah 'boom'. Sedangkan menurut (Yulianto, 2017) pelukis yang kreatif dan intens berkarya dari mulai boom "Suralisme Yogyakarta" adalah Koeboe Sarawan. Sementara untuk di Bandung, lukisan yang terkenal adalah dari Jelekong. Selaras dengan pemaparan (Alya, 2021) dalam penelitiannya memaparkan visualisasi pemandangan alam oleh para pelukis Jelekong telah menciptakan sebuah kualitas estetik.

Selain itu perlu disadari bahwa arus globalisasi memperngaruhi kebiasaan perilaku masyarakat yang dapat berimbas pada budaya lokal. Seperti halnya (Retnasary, Purba dan Saputra, 2019) yang meneliti strategi komunikasi komunitas Gurat dalam melestarikan seni lukis di desa Jelekong yang memaparkan bahwa anak-anak Jelekong mulai meninggalkan budaya seni melukis di desa mereka sehingga dibentuklah komunitas Gurat yang didirikan pada tahun 2010 sebagai bentuk pelestarian budaya melukis agar anak-anak menyukai melukis.

Para pelukis di kawasan jelekong tidak memiliki pendidikan seni namun mereka belajar secara otodidak. Gaya seni lukis di Kampung Seni Jelekong itu beragam diantaranya, teknik pisau palet dan sapuan kuas biasa hingga cokcrok. Teknik terakhir merupakan cara melukis dengan spon yang muncul akhir 1990-an. Teknik ini sangat diminati pembeli bahkan bertahan saat ini. Para pelukis memadukannya dengan teknik pisau palet untuk pemandangan alam. Sentra ini memiliki perajin yang ahli melukis panorama pedesaan, pacuan kuda, buahbuahan, ikan koi dan adu ayam (Nurhayati, 2018).

Penting bagi pelaku usaha untuk melakukan pemasaran atau kegiatan yang dapat ditawarkan oleh satu pihak kepada pihak lainnya. Keputusan konsumen memilih atau membeli tergantung pada bagaimana penyedia produk tersebut mengenalkannya kepada masyarakat luas. Maka bagi pelaku bisnis sangat penting untuk melakukan suatu kegiatan pemasaran untuk mendorong dan meningkatka penjualan seperti yang diharapkan. Maka dari itu, dibutuhkan strategi yang matang untuk berebut target konsumen di pasar. (Sunaryo Prayitno \& Rudy Harjanto, 2017:7-25) menyusun strategi komunikasi pemasaran dimulai dari perencanaan pemasaran. Unsur-unsur utama esensi pemasaran, antara lain: (1) proses pengelolaan elemen-elemen pemasaran, khususnya produk dan atributnya; (2) upaya pemenuhan keinginan dan kepuasan konsumen; dan (3) pertukaran nilai, dan (4) penciptaan hubungan dalam jangka waktu yang Panjang.

Menurut (Prayitno, 2017) ada tiga hal untuk mengukur perencanaan pemasaran, yaitu: (1) pangsa pasar; (2) volume penjualan; dan (3) biaya. Biaya merupakan penggerak dalam strategi pemasaran dalam semua bisnis. Biaya dibagi menjadi dua bagian yaitu biaya tetap (fixed cost) dan biaya variable (variable cost). Misalnya, biaya-biaya material maupun non material yang digunakan untuk biaya produksi (Panuju, Redi, 2019:70) 
Setelah memahami perencanaan pemasaran juga harus paham akan manajemen pemasaran. Menurut American Marketing Society dalam buku (Kotler dan Keller, 2016:27) Menyatakan bahwa Marketing management as the art and science of choosing target markets and getting, keeping, and growing customers through creating delivering, and communicating superior customer value. Definisi tersebut menyatakan bahwa Manajemen pemasaran sebagai seni dan ilmu dalam menentukan target pasar dan mendapatkan, mempertahankan, dan meningkatkan pelanggan dengan menyampaikan, dan mengkomunikasikan nilai pelanggan yang unggul (Hermawan, Fajar Tri, 2020).

Sedangkan menurut (Suparyanto \& Rosad, 2015:1) manajemen pemasaran adalah proses menganalisa, merencanakan, mengatur, dan mengelola program-program yang mencakup pengkonsepan, penetapan harga, promosi dan distribusi dari produk, jasa dan gagasan yang dirancang untuk menciptakan dan memelihara pertukaran yang menguntungkan dengan pasar sasaran untuk mencapai tujuan perusahaan.

"Marketing is the activity, set of institutions, and processes for creating, communicating, delivering, and exchanging offerings that have value for customers, partners, and society at large." Maksudnya bahwa pemasaran merupakan suatu aktivitas, kumpulan institusi dan juga proses untuk menciptakan, mengkomunikasikan, memberi dan pertukaran penawaran yang memiliki nilai, bagi customer, rekan-rekan dan masyarakat luas (Kotler dan Keller,2016:27).

Sedangkan menurut (Rut Christiyani, 2019:9) pemasaran adalah kegiatan untuk mencapai sasaran perusahaan dalam menangkap target pasar dan meningkatkannya dengan cara mengkomunikasikannya kepada customer mengenai kebutuhannnya sehingga produsen dapat mengetahui, memahami dan memenuhi kebutuhan dari customer itu sendiri. Ilmu marketing atau pemasaran lebih tinggi dari sekadar menjual atau berdagang. Manajemen pemasaran mencakup juga mengenai 'rekayasa produksi yang sesuai dengan kebutuhan pasar'. Selain itu mengenai kualitas, trend, jumlah produksi, desail harus diproduksi diperoleh dari bidang pemasaran (Musfar, Tengku Firli, 2020:2).

Maka dari itu dalam pemasaran, pengusaha harus mengetahui strategi pemasaran yang biak itu seperti apa agar dapat menjangkau pasar sasarannya, maka setiap perusahaan perlu mengelola kegiatan marketing-nya dengan baik. Perusahaan harus dapat Menyusun serta menggunakan marketing-mix untuk mengantisipasi perubahan serta mempengaruhi permintaan produk perusahaan. Menurut (Kotler dan Amstrong, 2016:51) bauran pemasaran (marketing mix) adalah seperangkat alat pemasaran taktis yang dipadukan perusahaan untuk menghasilkan respons yang diinginkannya di pasar sasaran yaitu dengan bauran pemasaran 7P (product, price, place, promotion, people, physical evidence, dan process) sehingga dapat mencapai marketing objective-nya dengan efektif, sekaligus memuaskan kebutuhan dan keinginan konsumen.

Fenomena pemasaran lukisan saat ini di Kampung Seni Budaya Jelekong bisa dianalisis melalui bauran pemasaran 7P. Pertama produk, lukisan Jelekong banyak ragamnya ada yang menggunakan kuas biasa, teknit valet, teknik spons dan lainnya. Produk lukisan ini sudah terkenal ke manca negar. Kedua price, mengenai harga sendiri itu bervariasi dimulai dari Rp 50.000 sampai jutaan rupiah. Harga tergantung kerumitan dari konsumen, namun banyak juga seniman yang menawarkan jasa belajar melukis selain itu juga bisa mural panggilan untuk daerah terpencil dengan harga dimulai Rp. 350.000 per meter persegi. Ketiga place, banyak masyarakat yang membuka jasa melukis di kawasan daerah tersebut karena 
memang mayoritas adalah seniman. Keempat promotion, untuk sekarang seniman, pengepul, pedagang lukisan Jelekong sudah mempromosikan produknya melalui berbagai $e$-commerce. Kelima people, seperti yang sudah diketahui bahwa dalam kampung tersebut mayoritas adalah seniman khususnya melestarikan budaya Sunda. Keenam physical evidence biasaya komunitas penggerak wisata (Kompepar) Jelekong memberikan tiket masuk untuk kawasan 2D \& 3D Gurat. Terkadang memberikan paket belajar melukis dalam hari besar bersejarah Indonesia dan terakhir mengenai process, karena keseharian masyarakat Jelekong umumnya adalah pelukis dan seniman maka proses mengenai pembuatan lukisan dimulai pra melukis menyiapkan kanvas dan alat lukis cepat karena sudah professional. Selanjutnya pemaparan lebih lanjut akan lebih mendalam mengenai analisis bauran pemasaran 7P di Kampung Seni Budaya Jelekong akan dipaparkan dalam artikel ini.

\section{LANDASAN TEORI}

Strategi pada hakikatnya adalah perencanaan (planning) dan manajemen untuk mencapai suatu tujuan. Akan tetapi, untuk mencapai tujuantersebut, strategi tidak berfungsi sebagai peta jalan yang hanya menunjukan arah saja, melainkan harus mampu menunjukan bagaimana taktik operasionalnya (Effendy,2017:32).

Handayani (2019) mengutip pendapat Kotler (2009) yang memaparkan mengenai marketing mix "Marketing mix is the set of marketing tools that the firm uses to puspose it's marketing objectives in the target market" bauran pemasaran merupakan sekumpulan alat pemasaran (marketing mix) digunakan perusahaan untuk tujuan pemasaran dalam pasar sasaran. Pendekatan pemasaran jasa telah dikembangkan sebuah alat terpenting (marketing mix) yang selanjutnya dalam marketing mix dikenal dengan istilah 7P sebagai alat marketing yang di dalamnya terdapat Product, Price, Place, Promotion, People, Physical evidence, dan Process (Maisah dkk,2020). Marketing mix bertujuan agar masyarakat dapat menciptakan produk baru serta membuka lapangan kerja agar menambah penghasilan (Wisudawati \& Sulistyowati, 2019).

Sementara untuk pemasaran jasa diperlukan bauran pemasaran yang luas dengan pengembangan unsur di perusahaan. Unsur-unsur yang terdapat dalam pemasaran terdiri dari tujuh aspek utama. Pemasaran jasa itu segala bentuk tindakan yang ditawarkan kepihak lain yang tidak terwujud. Alat pemasarannya dikenal dengan istilah "4P" yang kini berkembang menjadi "7P" untuk pemasaran jasa. Faktor-faktor penting dalam bauran pemasaran mengenai 4P (product, price, place, promotion), 7P (product, price, place, promotion, people, process, physical evidence) ada juga 4C (custumer value, cost, convenience, communication). Berikut penjelasan bauran pemasaran 7P (Musfar, T F, 2020:12-17):

1. Product (produk) adalah barang yang dibuat atau diproduksi untuk memenuhi kebutuhan sekelompok orang tertentu. Produk ini bisa berwujud atau tidak berwujud karena bisa dalam bentuk jasa atau barang. Suatu produk memiliki siklus hidup tertentu yang mencakup fase pertumbuhan, fase kematangan, dan fase penurunan penjualan. Maka pemasaran harus bisa menemukan kembali dan merangsang permintaan lebih banyak setelah mencapai penurunan penjualan.

2. Price (Harga) pada dasarnya adalah jumlah yang dibayar pelanggan untuk menikmatinya. Harga merupakan komponen yang sangat penting dari rencana pemasaran karena menentukan keuntungan dan kelangsungan hidup suatu perusahaan. Ada tiga strategi penetapan harga utama yaitu: 1) Harga penetrasi pasar; 2) Pasar menggelapkan harga; dan 3) Harga netral. 
3. Place (tempat) merupakan bagian yang sangat penting dalam distribusi. Perusahaan harus memposisikan dan mendistribusikan produk di tempat yang sudah diakses oleh pembeli potensial. Secara umum ada 3 strategi distribusi, yaitu: 1) Distribusi intensif; 2) Distribusi ekslusif; dan 3) Distribusi selektif.

4. Promotion (promosi) merupakan komponen pemasaran yang sangat penting karena dapat meningkatkan brand recognition dan penjualan. Promosi terdiri dari berbagai elemen seperti: periklanan, promosi penjualan, hubungan masyarakat, publisitas, event sponsorship, dan penjualan langsung.

5. People (orang) yang dimaksud sebagai bagian bauran pemasaran adalah dari orang yang berhubungan langsung saat bisnis. Ketika sebuah bisnis menemukan orangorang yang benar-bennar percaya akan produk atau layanan yang diciptakan oleh bisnis tertentu, kemungkinan besar karyawanakan melakukan yang terbaik semampu mereka.

6. Process (proses), jadi perusahaan harus memastikan bahwa perusahaan memiliki proses yang disesuaikan dengan baik untuk meminimalkan biaya.

7. Physical evidence (bukti fisik) di industri jasa, harus ada bukti fisik bahwa layanan tersebut disampaikan. Selain itu bukti fisik juga berkaitan dengan bagaimana bisnis dan produk itu dirasakan di pasar.

\section{METODE PENELITIAN}

Penelitian ini menggunakan metode kualitatif pendekatan studi kasus dengan menggambarkan kondisi objek yang diteliti sesuai fakta yang ada kemudian dihubungkan dengan strategi pemasaran lukisan yang akan dieliti. Data yang diperoleh melalui wawancara mendalam, observasi, dan dokumentasi. Subjek penelitian ini adalah seseorang yang merupakan ketua kompepar Jelekong, salah satu pengelola Gurat dan pelukis yang mengelola Kampung Seni Budaya Jelekong. Sedangkan teori yang digunakan adalah bauran pemasaran 7P yang meliputi (Product, Place, Price, Promotion, People, Physical avidence, dan Process) yang dilakukan oleh komunitas seniman Jelekong. Berikut adalah informan yang penulis wawancarai:

Tabel 1 Data Informan yang di wawancara

\begin{tabular}{|l|l|l|l|}
\hline No & \multicolumn{1}{|c|}{ Informan } & \multicolumn{1}{|c|}{ Keterangan } & \multicolumn{1}{c|}{ Pengalaman } \\
\hline 1 & Intan Sunarya & $\begin{array}{l}\text { Ketua Komunitas Penggerak } \\
\text { Wisata (Jelekong) }\end{array}$ & $\begin{array}{l}\text { Mengurus dan mengelola apabila ada } \\
\text { wisatawan yang ingin belajar melukis atau } \\
\text { wawancara yang nantinya akan di arahkan. }\end{array}$ \\
\hline 2 & Bapak Oding & $\begin{array}{l}\text { Sesepuh \& seniman di } \\
\text { Kampung Seni Budaya Jelekong }\end{array}$ & $\begin{array}{l}\text { Sering mengadakan pagelaran, membimbing } \\
\text { masyarakat sekitar untuk menyukai kesenian } \\
\text { daerah. }\end{array}$ \\
\hline 3 & Kang Iyus & Fasilitator Gurat Art & $\begin{array}{l}\text { Gurat Jelekong sebelum pandemi pernah } \\
\text { booming di media massa karena lukisan 3D } \\
\text { Trick art yang menarik. Komunitas Gurat sering } \\
\text { melakukan mural di daerah lain juga yang } \\
\text { sistemnya panggilan. }\end{array}$ \\
\hline 4 & Anggi & Pelukis & $\begin{array}{l}\text { Lukisannya sudah dijual ke manca negara. } \\
\text { Setiap hari mampu menyelesaikan 7 lukisan } \\
\text { alam. }\end{array}$ \\
\hline
\end{tabular}

Sumber: Olahan peneliti hasil wawancara tahun 2021

Keempat informan tersebut telah memenuhi kriteria karena selain semuanya seniman yang kesehariannya berkutik dalam hal seni rupa juga merupakan orang-orang pilihan yang selalu melestarikan budaya daerah di Jelekong. Intan Sunarya yang merupakan cucu dari 
Abah Sunarya seniman terkenal yang mewakili Jawa Barat yang kini menjadi ketua komunitas penggerak wisata Jelekong. Bapak Oding, Kang Iyus dan Anggi pelukis yang lukisannya sudah dijual sampai mancanegara dan banyak keahlian yang mereka kuasai selain untuk menjual produknya juga mengajak masyarakat sekitar bahkan pengunjung untuk belajar melukis.

Peneliti melakukan wawancara secara langsung menemui keempat informan di Kampung Seni Budaya Jelekong. Selain itu peneliti juga melakukan observasi lanjutan. Observasi adalah suatu cara pengumpulan data dengan pengamatan langsung dan pencatatan secara sistematis terhadap obyek yang akan diteliti. (Sugiyono, 2017:310-313) dalam buku Analisis Data Kualitatif Wijaya, Umrati Hengki (2020) bahwa observasi dibagi menjadi dua bagian yakni: pertama, observasi secara terang-terangan atau tersamar pada saat melakukan pengumpulan data dan kedua observasi tak berstruktur tidak disiapkan secara sistematis tentang apa yang akan diobservasi. Observasi ini dipakai karena peneliti tidak tahu secara pasti tentang apa yang akan diamati. Dalam instrumen pengamatan, peneliti tidak menggunakan instrument yang telah baku tetapi hanya berupa rambu-rambu pengamatan. Tujuan dari observasi adalah untuk mendiskripsikan setting, kegiatan yang terjadi, orang yang terlibat di dalam kegiatan, waktu kegiatan dan makna yang diberikan oleh para pelaku yang diamati tentang peristiwa yang bersangkutan.

Selain itu dalam penelitian ini melakukan pengumpulan data berupa tinjauan literatur dalam jurnal, buku-buku, serta pemberitaan media massa yang terkait dengan tema yang dibahas untuk mendapatkan hasil temuan yang relevan dengan topik yang dibahas dalam artikel ilmiah ini dan terakhir adanya dokumentasi untuk pendukung penelitian.

\section{PEMBAHASAN}

\section{Awal mula berdiri Kampung Seni Budaya Jelekong}

Kampung seni budaya Jelokong merupakan salah satu kampung seni di Kabupaten Bandung yang didirikan secara turun temurun karena mayoritas penduduknya adalah seniman. Mulanya ada satu keluarga Abah Sunarya yang menjadi dalang dan suka melukis yang pada akhirnya masyarakat Jelekong sepakat menjadikan kampung tersebut menjadi Kampung Seni Budaya Jelekong. Menurut Intan Sunarya pada saat ditemui dan diwawancara oleh peneliti, jika mengingat kebelakang Abah Sunarya memiliki 13 anak yang 6 diantaranya menjadi dalang dan keturunan-keturunanya juga meneruskan sehingga dalam satu kampung ada 22 dalang yang biasanya di kampung lain hanya ada 1 dalang saja. Selain itu keluarga yang senang melukis secara otodidak juga membuat lukisan khas Jelekong itu terkenal. Berikut hasil wawancara dengan narasumber:

"Menurut sejarah Kampung Seni Budaya Jelekong ini berdiri sejak ratusan tahun yang lalu, hanya saja disebut Kampung Seni Budaya Jelekong ini ketika muncul suatu seni sunda yaitu seni wayang yang di bawakan oleh Mbah Sunandar dan seni lukis. Tujuan didirikannya Kampung Seni Budaya Jelekong ini untuk memperkenalkan budaya, khususnya budaya lokal yang ada di Kampung Jelekong seperti seni lukis, seni wayang, seni pahat, seni tari hingga ada kuliner khas Jelekong"

Selain itu Pemerintah daerah kabupaten Bandung memberikan predikat desa wisata untuk mengidentifikasi aspek kepariwisataan yang kreatif di Kampung Seni Budaya Jelekong. Peraturan Bupati Bandung nomor 556.42/kop.71-DISPOPAR/2011 tentang penetapan 10 Desa Wisata di wilayah Kabupaten Bandung yang mencakup agrowisata yaitu Desa Alam Endah, Desa Gambung, Desa Panundaan, Desa Ciburial, Desa Laksana, dan Desa 
Rawabogo. Kerajinan tangan yaitu Desa Lebakmuncang, wisata minat khusus ada di Desa Lamajang, dan terakhir seni dan budaya ada di Desa Jelekong dan Desa Cinunuk. Seperti halnya berikut paparan dari narasumber:

"Pada tahun 2010 dibentuknya 10 Desa Wisata dan Kampung Jelekong termasuk didalamnya yang mendapatkan SK dari Bupati Bandung dan menjadikan Kelurahan paling unggul satu satu nya yang mendapat predikat sebagai Desa Wisata. Setelah mendapat SK sebagai Desa Wisata dari Bupati Bandung terbentuklah KOMPEPAR (Kelompok Penggerak Pariwisata), Kompepar tersebut dibagi menjadi dua yaitu Kompepar Giriharja dan Kompepar Gentong yang berfungsi sebagai pengurus dan pengelola Kampung Seni Budaya Jelekong. Kompepar Giriharja manaungi kesenian wayang, lukisan dan seni tari, sedangkan Kompepar Gentong menaungi kelestarian alam dan kuliner."

Pendukung lain mengacu pada landasan yuridis seperti instruksi presiden Republik Indonesia Nomor 16 tahun 2005 tentang kebijakan pengembangan kebudayaan dan pariwisata. Keputusan gubernur kepala daerah tingkat I Provinsi Jawa Barat Nomor 15 Tahub 1997 tentang kelompok penggerak pariwisata (KOMPEPAR). Undang- Undang Nomor 22 Tahun 1999 tentang pemerintah daerah dan peraturan daerah Nomor 7 Tahun 1996 tentang pembinaan, pengembangan, dan pelestarian seni budaya daerah di Jawa Barat.

Namun, Kompepar Giriharja sengaja dibentuk dengan tujuan meningkatkan peran pelaku usaha pariwisata dan masyarakat dalam menata pelayanan dan kebutuhan wisatawan di obyek dan daya tarik wisata, meningkatkan wisatawan, meningkatkan sadar wisata beredukasi seni dan budaya, yang paling utama tentunya menciptakan Giriharja Jelekong sebagai daerah tujuan budaya dan wisata andalan.

Setelah dibentuk Kompepar Giriharja, pengelola mendata sekitar kurang lebih 1000 pengunjung sudah memasuki kawasan wisata seni budaya yang di dalamnya juga ada wisatawan dari luar negeri yang berasal dari Amerika, Malaysia, Cina, Perancis, Belgia, Sri Langka dan Rusia. Masyarakat juga menyediakan layanan akomodasi seperti disediakannya homestay. Sehingga Kompepar Giriharja menjadi finalis ke 5 kelompok sadar wisata kategori mandiri tingkat nasional pada tahun 2019 yang diselenggarakan oleh Kementrian Pariwisata

\section{Strategi Pemasaran Kampung seni Budaya Jelekong}

Sektor pariwisata merupakan faktor yang mempengaruhi perekonomian Desa Jelekong. Banyak tempat objek wisata yang menjadi kekayaan sendiri bagi daerah Bandung. Salah satunya adalah desa wisata Kampung Seni Budaya Jelekong di Kelurahan Jelekong Kabupaten Bandung. Desa wisata ini dikelola oleh Kompepar (Kelompok Penggerak Pariwisata) yang telah disetujui oleh Bupati Bandung pada tahun 2010.

Dengan adanya strategi komunikasi pemasaran yang baik dalam melakukan pemasaran maka hasilnya akan baik pula. Hal demikian yang akan meningkatkan jumlah kunjungan wisatawan dan membantu perekonomian masyarakat Desa Jelekong. Menurut Kompepar ada baiknya mengetahui terlebih dahulu target sasaran yang akan dituju, agar pesan yang dibuat dapat sampai kepada sasaran.

Menggunakan strategi komunikasi pemasaran dapat mendorong desa wisata Jelekong agar diketahui oleh masyarakat luas serta siap untuk berlomba dengan 9 desa wisata lainnya yang ada di Kabupaten Bandung. Berikut akan dipaparkan hasil wawancara peneliti dengan 
beberapa informan. Pertama mengenai produk yang diproduksi yang menjadi icon di Kampung Seni Budaya Jelekong adalah wayang, lukisan, dan kesenian lainnya yang bersifat home industry.

"Produknya adalah lukisan selain sebagai tempat wisata, ada juga home industry yang menjual berbagai macam makanan tradisional dan Wayang."

Meskipun bersifar home industy namun menurut Kang Iyus pada saat ditemui dan diwawancarai, dalam mengelola desa wisata Jelekong itu sudah bekerja sama dengan mahasiswa yang ada di Kota Bandung seperti Universitas Maranata, UPI, UNPAD, bahkan mahasiswa dari luas negeri pun ikut serta dalam memajukan Kampung Seni Budaya Jelekong.

Kedua, menegenai harga sebenarnya tidak ada patokan harga karena setiap seniman berbeda-beda menawarkanya. Ada yang hanya menyediakan alat lukisnya saja seperti kanvas, cat, papan lukis atau ada yang dating ke pelukisnya langsung dengan membeli lukisan yang sudah jadi. Ketiga, mengenai tempat pengunjung bisa dating langsung ke Galeri seni lukis dimulai di gapura depan Giriharja sampai Gentong, yang di mana ada 105 RT dan 14 RW. Bisa bebas memilih berkunjung dan belajar melukis ke galeri yang mana sesuai keinginan. Namun biasanya suka di arahkan terlebih dahulu oleh komunitas penggerak pariwisata Jelekong (Kompepar). Terakhir mengenai promosi ketua kompepar Giri Harja dan ketiga informan lainnya mengaku hamper semua bentuk promosi sudah dilakukan dimulai dari media online, pameran event, public relations.

Mayoritas masyarakat Jelekong adaah seniman maka tidak heran mereka giat dan melestarikan budaya terutama kesenian Sunda yang sudah turun temurun dan membuat Kampung Seni Budaya Jelekong terkenal.

"Desa wisata ini dikelola oleh semua masyarakat yang tinggal di Kampung Jelekong, jadi kami sama sama untuk menjaga dan merawat desa wisata ini. Selain lukisan, ada juga yang menjual wayang dan assesoris lucu seperti mug, kaos, gantungan yang bertemakan kesenian sunda”.

Dengan strategi yang telah dilakukan oleh Kompepar, Kampung Seni Budaya Jelekong ini sudah banyak wisatawan yang berkunjung. Kebanyakan wisatawan tertarik dengan seni lukisnya hingga harga lukisan pun dari yang harga murah sampai mahal ada. Masyarakat Desa Jelekong ini hampir 20\% masyarakatnya berprofesi sebagai seniman, sampai sampai kehidupan sehari hari nya pun berketergantungan pada lukisan.

\section{Analisis Bauran Pemasaran 7P di daerah Jelekong}

Bauran pemasaran dalam penelitian ini merupakan controllable marketing variable sehingga perusahaan dapat mencapai tujuannya dengan efektif, sekaligus memuaskan kebutuhan dan keinginan konsumen, pendekatan pemasaran tersebut terdiri dari bauran pemasaran 7P yaitu (produc, place, price, promotion, people, physical evidence, dan process).

Keempat informan mengaku bahwa di Kampung Seni Budaya Jelekong itu sudah melakukan pemasaran dan promosi dalam berbagai cara seperti halnya berikut hasil wawancara dengan salah satu informan:

"Pemasaran apapun sudah kami coba lakukan semuanya untuk mempromosikan desa Jelekong ini kepada khalayak luas mulai dari di televisi, radio, banner kami pasang 
dimana-mana, petunjuk arah mulai dari daerah Baleendah. Itu semua untuk mempromosikan Kampung Seni Budaya Jelekong, serta bertujuan untuk meningkatkan pelayanan produk wisata, dan mengenalkan nya pada saat pertunjukkan/event."

Peneliti akan memaparkan bauran pemasaran 7P yang ada di Kampung Seni Budaya Jelekong, diantaranya:

\section{1.Product (produk)}

Sesungguhnya pelanggan tidak membeli barang atau jasa, tetapi membeli manfaat dan nilai dari sesuatu yang ditawarkan. 'Apa yang ditawarkan' menunjukkan sejumlah manfaat yang bisa pelanggan dapatkan dari pembelian suatu barang atau jasa.

Lukisan yang ditawarkan di Kampung Seni Budaya Jelekong itu beragam namun banyaknya memproduksi mengenai alam, tumbuh-tumbuhan, hewan, karakter budaya dengan teknik gaya seni lukis teknik pisau palet dan sapuan kuas biasa hingga cokcrok.

\section{Price (harga)}

Penentuan harga titik krisis dalam bauran pemasaran jasa karena harga menentukan pendapatan dari suatu usaha/bisnis. Keputusan penentuan harga sangat signifikan didalam penentuan nilai/manfaat yang ada diberikan kepada pelanggan dan memainkan peranan penting dalam gambaran kualitas dari jasa.

Anggi selaku pelukis asli Jelekong memaparkan bahwa lukisan yang dipesan itu beragam tergantung minat konsumen dengan harga ukuran kanvas $30 \mathrm{~cm}$ X $40 \mathrm{~cm}$ itu Rp. 25.000 , berukuran $60 \mathrm{~cm} \times 80 \mathrm{~cm}$ Rp. 50.000 , berukuran $100 \mathrm{~cm}$ x $100 \mathrm{~cm} \mathrm{Rp.} 100.000$. Sementara untuk lukisan kecil-kecil yang sudah jadi seperti bunga, pemandangan, abstrak itu dijual dengan harga Rp. 15.000 saja.

\section{Place (tempat)}

Tempat merupakan berbagai kegiatan yang dilakukan oleh perusahaan untuk membuat produknya mudah diperoleh dan tersedia pada konsumen pemasaran. Distribusi juga mempunyai peranan penting dalam pemasaran untuk menyediakan barang dan jasa yang diperlukan oleh konsumen. Dahulu memang tempat itu dijadikan suatu pertimbangan yang penting bagi konsumen dalam berbelanja. Namun menurut Dwinanda \& Nur (2020) saat ini banyak aplikasi yang memudahkan konsumen melakukan pembelian tanpa harus berkunjung ke tempatnya, seperti halnya jika ingin membeli produk lukisan Jelekong kini bisa melalui online karena tersedia di berbagai market place.

Desa wisata ini berlokasi di Jl.Giriharja, Kelurahan Jelekong, Kabupaten Bandung, Jawa Barat hingga desa gentong. Desa wisata ini dipegang oleh 2 Kompepar yaitu Kompepar Giriharja dan Kompepar Jelekong, dengan jumlah seniman kurang lebih ada 500 orang.

\section{Promotion (promosi)}

Promosi merupakan aktivitas marketing yang dilakukan perusahaan untuk mengkomunikasikan dan mempromosikan produknya kepada pasar sasaran bisa dengan iklan, tenaga penjual, promosi penjualan, public relations dan direct marketing. Ramadhanti melakukan penelitian pada tahun 2017 selain promosi, faktor yang mempengaruhi konsumen dalam memutuskan pembelian diantaranya kebiasaan dalam membeli, penyesuaian kebutuhan dan keinginan, keyakinan dan rekomendasi. 
Dari keseluruhan bentuk promosi yang dilakukan Kompepar Giriharja, komunitas seni, Gurat, prioritas utama promosi dilakukan melaui event, public relation direct marketing. Kompepar Giriharja aktif dalam event baik yang diselenggaran oleh Kompepar Giriharja maupun digelar oleh pihak lain, event tersebut berupa pagelaran wayang, pameran lukisan dan lainnya. Promotion tools yang dilakukan Kampung Seni Budaya Jelekong diantaranya:

Tabel 2 Promotion tools Kampung Seni Budaya Jelekong

\begin{tabular}{|l|l|l|}
\hline No & \multicolumn{1}{|c|}{ Promotion Mix } & \multicolumn{1}{c|}{ Bentuk } \\
\hline 1. & Advertising & Feature di televise \\
\hline 2. & Event \& Experiences & Seminar, kelas melukis, kunjungan wisata ekspresif \\
\hline 3. & PR \& Publicity & Berita di media online \\
\hline 4. & Direct Marketing & Sosial Media \\
\hline 5. & Interactive Marketing (Pemasaran Interaktif) & Live facebook/ Instagram/ youtube \\
\hline 6. & $\begin{array}{l}\text { Word of Mouth Marketing (pemasaran dari } \\
\text { mulut ke mulut) }\end{array}$ & Dokumenter media ternama \\
\hline 7. & Personal Selling (penjualan perseorangan) & Sanggar lukis Giri Harja \\
\hline
\end{tabular}

Sumber: Olahan Peneliti, 2021

\section{People}

Seniman di Kampung Seni Budaya Jelekong mengasah kemampuannya dengan otodidak. Selain itu mereka juga sering mural ke berbagai tempat guna sosialisasi dengan seniman yang lain dan terus mengasah kemampuan melukis mereka. Komunitas gurat juga mengadakan kelas belajar melukis untuk pelajar dan pengunjung. Karena selaras dengan pendapat Philip Kotler yaitu proses seleksi, pelatihan dan pemotivasian karyawan yang nantinya dapat digunakan sebagai pembeda perusahaan dalam memenuhi kepuasan konsumen. (Wisudawati \& Rizalmi, 2020) people merupakan bagian suatu pelayanan penjualan yang baik / partisipasi layanan, edukasi penjualan ke konsumen, norma objektif (mengucap salam dan mengedukasi calon pembeli).

Karyawan di kampung Seni Budaya Jelekong ini bisa dikatakan mayoritas seniman yang kuat kaitannya dengan kesenian Sunda karena awal mula Kampung Seni Budaya Jelekong itu Abah Sunarya yang melestarikan kesenian Sunda dengan wayang dan lukisan. Pengunjung atau konsumen yang dating juga beragam bukan hanya dari daerah Indonesia namun dari manca negara juga sering melakukan penelitian.

\section{Physical Evidence}

Kampung Seni Budaya Jelekong memberikan service kepada pengunjungan dengan memberikan tempat untuk komunitas melukis, berkumpul yang dilengkapi dengan alat-alat kesenian, berupa gazebo, taman kecil, foto dokumentasi saat kunjungan, dan kenangan sebuah lukisan. Selain itu seniman Jelekong suka memberikan sampel lukiasan untuk penjualan ekspor sehingga konsumen tau kualitas lukisan Jelekong itu seperti apa.

Pengunjung bisa belajar melukis diarahkan oleh seniman dan hasil lukisannya bisa dibawa pulang. Selain itu komunitas penggerak wisata Jelekong menyediakan data-data apabila pengunjung ingin mengetahui lebih jauh mengenai Kampung Seni Budaya Jelekong 
dengan pelayanan yang ramah, biasaya mahasiswa yang sering melakukan penelitian diberikan beberapa data guna memenuhi penelitiannya.

\section{Process}

Proses yaitu prosedur aktual, mekanisme dan aliran aktivitas dengan mana jasa disampaikan yang merupakan sistem penyajian atas operasi jasa atau proses merupakan bentuk kegiatan yang dilakukan untuk memasarkan produk barang atau jasa kepada calon pelanggan. Karena jika dilihat dari sudut pandang konsumen produk jasa dilihat dari bagaimana proses jasa menghasilkan fungsi. Berikut paparan hasil wawancara dengan salah satu informan:

"Prosesnya, semua wisatawan yang datang kami layani dengan baik, bila mereka ingin melihat tata cara pembuatan wayang kami bawa ajak untuk melihat proses pembuatannya, sama juga dengan pembuatan lukisan. Sekarang ada yang baru di Kampung Seni Budaya Jelekong yaitu wisata Gurat, tempat ini berisi tempat untuk selfi $3 D$ dan menyediakan kanvas serta cat nya jika pengunjung ingin melukis."

Seniman di kampung seni budaya Jelekong setiap harinya pasti melakukan kegiatan melukis. Namun, seniman juga melayani orderan dari luar dengan minat konsumen yang berbeda. Selain itu juga melayani wisatawan dengan sepenuh hati dari mulai menjemput dan menyediakan tempat parkir, hingga berkeliling di Kampung Seni Budaya Jelekong. Masyarakat jelekongpun memberikan pelayanan bagi yang hendak belajar melukis. Selain itu poin positif juga biasanya masyarakat Jeelekong memberikan pengetahuan juga tentang kesenian yang ada di desa Jelekong, seperti cara pembuatan wayang, pembuatan lukisan, home industry seperti pembuatan assesoris dan makanan tradisional.

\section{KESIMPULAN DAN SARAN}

\section{KESIMPULAN}

Pada dasarnya pemasaran lukisan di Kampung Seni Budaya Jelekong sudah melakukan strategi bauran pemasaran 7P. Bauran pemasaran 7P yang lebih ditingkatkan saat ini yaitu mengenai promosi karena pandemi ini membuat konsumen yang datang ke Kampung Seni Budaya Jelekong menurun, yang menjadi prioritas utama promosi dilakukan public relations, direct marketing, serta event. Mereka menganggap bahwa strategi ini menjadi wadah bagi kebutuhan pemasaran seniman. Sehingga dalam melakukan implementasi seniman Jelekong tidak mengalami kendala yang berarti karena setiap harinya pasti melakukan produksi melukis.

Saat ini seniman lebih dapat memetakan mana produk yang diminati masyarakat luas. Lukisan yang ditawarkan di Kampung Seni Budaya Jelekong itu beragam namun banyaknya memproduksi mengenai alam, tumbuh-tumbuhan, hewan, karakter budaya dengan teknik gaya seni lukis teknik pisau palet dan sapuan kuas biasa hingga cokcrok.

\section{SARAN}

Pada tahap strategi pemasaran perlu dibuat program yang lebih spesifik dalam jangka waktu yang lebih lama agar lukisan Jelekong tetap Berjaya. Selain itu lebih bisa mempromosikan di media online agar target pasarnya meningkat dan banyak melakukan sosialisasi ke sekolah-sekolah. 
Keterbatasan dalam penelitian ini adalah hanya meneliti mengenai seni lukisnya saja, alangkah lebih baik untuk peneliti selanjutnya bisa meneliti bauran pemasaran mengenai seluruh produk dan jasa yang ada di Kampung Seni Budaya Jelekong misalnya meneliti mengenai wayang goleknya, kesenian daerahnya dan sebagainya.

\section{DAFTAR PUSTAKA}

Alya, Shopia Himatul. (2021). Lukisan Pemandangan: Teknik Spon Dalam Karya Seni Lukis Jelekong. Jurnal Ilmu Pendidikan Nonformal. Vol7, No.1. DOI: http://dx.doi.org/10.37905/aksara.7.1.103-110.2021

Christiyani, Rut. (2019). Strategi Pemasaran Selasar Sunaryo Art Space Sebagai Wisata Seni di Kota Bandung. Skripsi. Sekolah Tinggi Pariwisata NHI Bandung.http://repository.stpbandung.ac.id/bitstream/handle/123456789/1062/RUT\%2 0CHRISTIYANI\%20201520472-2019.pdf? sequence $=1$

Dwinanda, Giri \& Nur, Yuswari. 2020. Bauran Pemasaran 7P dalam Mempengaruhi Keputusan Pembelian Konsumen Pada Industri Retail Giant Ekspress Makassar. Jurnal Mirai Management. Vol.6, No.1. DOI: https://doi.org/10.1234/mirai.v6i1.690

Effendy, Onong Uncjana. (2017). Ilmu Komunikasi Teori dan Praktek. Bandung:PT Remaja Rosdakarya

Handayani, Tati \& Fathoni, Muhammad Anwar.(2019). Buku Ajar Manajemen Pemasaran Islam. Yogyakarta:Penerbit Deepublish (Group Penerbitan CV Budi Utama)

Hermawan, Fajar Tri. 2020. Pengaruh Bauran Pemasaran Terhadap Keputusan Pembelian Motor Honda. Skripsi. Prodi S1 Manajemen, Sekolah Tinggi Ilmu Ekonomi Indonesia. http://repository.stei.ac.id/1738/

Kotler, Philip dan Gary Amstrong. 2016. Prinsip-prinsip Pemasaran Edisi 13Jilid 1. Jakarta: Erlangga.

Kotler, Philip \& Kevin Lane Keller. (2016) Marketing Management, 15th Edition. New Jersey: Pearson Pretice Hall, Inc

Maisah., Mahdayeni., \& Maryam.2020. Penerapan 7P Sebagai Strategi Pemasaran Pendidikan Tinggi. Jurnal Ekonomi dan Manajemen Sistem Informasi. Vol.1, Isu 4. DOI: https://doi.org/10.31933/jemsi.v1i4.116

Musfar, Tengku Firli. 2020. Manajemen Pemasaran. Bandung: Penerbit Media Sains Indonesia

Nurhayati. (2018). Pelatihan Manajemen Usaha dalam Meningkatkan Penjualan Lukisan Kampung Lukis Jelekong Kabupaten Bandung. Prosiding Seminar Nasional Hasil $\begin{array}{llll}\text { Pengabdian } & \text { Kepada } & \text { Masyarakat. } & \text { Bol.1, }\end{array}$ https://conference.upnvj.ac.id/index.php/pkm/article/view/26

Panuju, Redi. 2019. Komunikasi Pemasaran. Jakarta:Prenada Media Group 
Prayitno, Sunarto \& Rudy Hrjanto. 2017. Manajemen Komunikasi Pemasaran Terpadu. Jakarta: PT RajaGrafindo Persada,

Ramadhanti, Amalia. 2017. Pengaruh Bauran Pemasaran (7P) terhadap Keputusan Pembelian pada Giant Supermarket Mall Mesra Indah di Samarinda. E-Journal Administrasi Bisnis, Vol.5, No.2. https://ejournal.hi.fisip-unmul.ac.id/site/wpcontent/uploads/2017/05/JURNAL\%20(05-05-17-08-41-26).pdf

Retnasary, Maya., Purba, Veny \& Saputra, Muhamad D S. Jurnal JPR Medcom. Vol.1, No.1. DOI: https://doi.org/10.35706/jprmedcom.v1i1.3115

Suwitya, Dwi. (2018). Strategi Pemasaran Karya Seni Lukis. Jurnal Ekobis Dewantara. Vol.1, No.8. hlm. 67. http://jurnalfe.ustjogja.ac.id/index.php/ekobis/article/view/538

Suparyanto dan Rosad. 2015. Manajemen Pemasaran. Yogyakarta: In Media.

Yulianto. (2017). Estetika Seni Lukis Karya Koeboe Sarawan. Jurnal Seni Gelar Budaya. Vol.15, No.2. DOI: https://doi.org/10.33153/glr.v15i2.2223

Wijaya, Umrati Hengki. 2020. Analisis Data Kualitatif. Makassar: Sekolah Tinggi Theologia Jaffray

Wisudawati, T \& Sulistrowati. 2019. "Penerapan Metode Marketing Mix 7P Untuk Strategi Pemasaran Produk Daur Ulang”. Universitas Duta Bangsa Surakarta. https://ojs.udb.ac.id/index.php/SINTECH/article/view/874

Wisudawati, Tri \& Rizalmi, Sigit Rahmat. 2020. Analisis Metode Marketing Mix 7P Sebagai Strategi Pemasaran Produk Daur Ulang. Jurnal Science Innovation and Technology. Vol.1, No1. http://ojs.udb.ac.id/index.php/SINTECH/article/download/874/761/ 